\title{
The Effect of Lipid Composition in Diets on Ovicell Generating of the Russian Sturgeon Females
}

\author{
Fedorovykh JV*, Ponomarev SV, Bakaneva JM, Bakanev NM, Sergeeva JV, Bakhareva AA, Grozesku JN and Egorova VI
}

Astrakhan State Technical University (ASTU), Department of Aquaculture and Water Bioresources, 414056, Rus-sian Federation, Astrakhan, Tatishev st, 16, Russia

\begin{abstract}
This research is aimed to study the effect of lipid composition in diets on ovicell generating of the Russian sturgeon females. Addition of fish oil in number of $9 \%$ (with $12-13 \%$ total fat content in mixed fodder) proved to be an opti-mal rate of mixed fodder supplement with fish oil for both commodity sturgeon farming and pre-spawning maintenance of breeders with the view of improving the quality of the live fertilized roes and caviar alike. According to the data of biochemical analyses of the sturgeons body composition, hematological indices, growth rates and general condition of the cultivated fish the effect was rather positive. At a minimum expenditure of fodder the body weight gain of the fish body in these series of experiments amounted $3.2 \%$ with maximum possible level of survivability $(100 \%)$. Besides being highly nourishing fish oil also attracting.
\end{abstract}

Keywords: Dry feed; Fish oil; Fatty acids; Females; Gonads; Lipids; Sturgeon

Abbreviations: CP: Crude Protein; i-AA: Indispensable Amino Acids; ECR: Erythrocyte Sedimentation Rate; PUFA: Polyunsaturated Fatty Acids

\section{Introduction}

Artificial sturgeon farming has received a new incentive to development caused by invention and wide use of modern qualitative diets so it has become possible to get about 200 kilograms per square meter of fine fish commodity and solve the problem of import replacement. The quality of complete feed in use is one of the determinative factors of successful commercial fish-farming [1-3]. It ensures intensive growth and development of the fish without natural forage reserve, as well as availability of optimal basic nutrients balance particularly protein and fat, provision with such indispensable nutrients as amino and fatty acids, carotinoids, macroand microelements, vitamins [4,5]. For juveniles and tradable sturgeon (both type and hybrid species) farming it is necessary to use dry diets which is known to be the basis for normal breeder's gonad products development as well as for optimal growth and evolution of various age fish. However a great deal of untrimmed fodder contains about $20 \%$ of fat and fat content in fodders of various trademarks can be different $[6,7]$ and inconsistent with physiological needs of fish for unsaturated fatty acids. It can cause deranged development of ovicells, tissues and internal of fish [8-10]. This research is aimed to study the effect of lipid composition in diets on ovicell generating of the Russian sturgeon females (Figures 1 and 2).

\section{Material and Methods}

During the experiment with efficiency of the sturgeons' growth on combifodder -aimed for commodity farming- with different fat content and fatty acids composition juveniles of the Russian sturgeon were used as a subject of the research. The collection of samples for conducting biochemical and histological gametal cells analysis of Russian sturgeon females was taken at sturgeon fish hatcheries of Astrakhan oblast during spawning campaign. We carried out experimental work at the innovative centre of Astrakhan State Technical University (ASTU) "Biowater park - aquaculture scientific and technical centre". The fish was bred in direct-flowed water basins of $2 \times 2 \times 0,7$ meters size. Water temperature in basins during the experiment was $16,5-21,5^{\circ} \mathrm{C}$, oxygen concentration - 7,8-8,2 milligrams per liter, $\mathrm{pH}-7,3-7,5$. Since a female reaches the age of puberty the observance of diet feeding is of a great importance as it stimulates roe development and has an effect on fertility. This problem is rather complex - that's why diets is necessary to contain a great amount of assailable, food valued proteins, balanced amino acids required for the normal development of roe $[11,12]$. The optimal level of fat and linolenic ( $\omega 3)$ fatty acids allows to get high-quality piscicultural and food roe without accumulating excess mass of fat [13-15]. The experimental variants of mixed fodder recipes are presented in Table 1. Animal origin ingredients, foremost fish flour, are the richest in protein and indispensable amino acids. The abovementioned compounding contained fish flour produced of fresh anchovy sprat. It is distinguished with high level of lysine, methionine, arginine and other scarce amino acids determining normal growth and development of fish [16]. The protein and indispensable amino

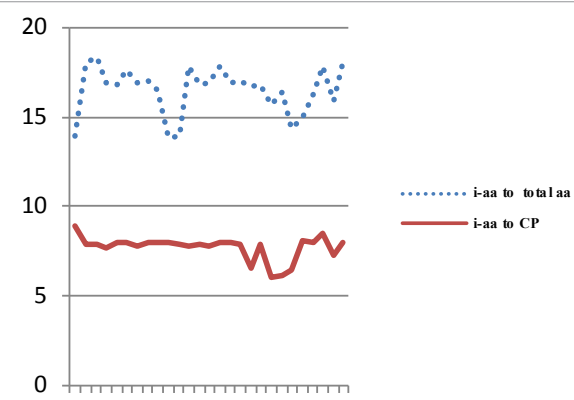

Figure 1: Lysine to crude protein and sum of i-AA ratio in fish flour.

*Corresponding author: Fedorovykh JV, Astrakhan State Technical University (ASTU), Department of Aquaculture and Water Bioresources, 414056, Russian Federation, Astrakhan, Tatishev st, 16, Russia, Tel: 7(8512)614163; E-mail: jaqua@yandex.ru

Received February 24, 2015; Accepted March 10, 2015; Published April 25, 2015

Citation: Fedorovykh JV, Ponomarev SV, Bakaneva JM, Bakanev NM, Sergeeva JV, et al.(2015)The Effect of Lipid Composition in Diets on Ovicell Generating of the Russian Sturgeon Females. J Aquac Res Development 6: 334 . doi: 10.4172/2155-9546.1000334

Copyright: ( 2015 Fedorovykh JV, et al. This is an open-access article distributed under the terms of the Creative Commons Attribution License, which permits unrestricted use, distribution, and reproduction in any medium, provided the original author and source are credited. 


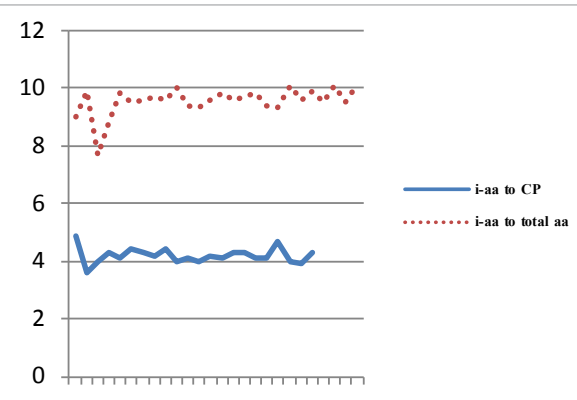

Figure 2: Threonine to crude protein and sum of i-AA ratio in fish flour.

acids content in fish flour produced of fresh anchovy sprat is presented in Table 2. At present crude protein percentage in fish flour doesn't necessarily mean high quality of this element $[17,18]$. In order to really estimate the quality of crude protein and subsequently make out an appropriate recipe it is necessary to know exact percentage of not "crude" protein (CP) but of "amino-acid protein" and indispensable amino acids (i-AA) especially in such macro ingredients with high protein content as fish flour. These graphs indicate the ratio of four basic indispensable amino acids - lysine, methionine, threonine and cystine to crude protein and sum of indispensable for fish flour amino acids. The ratio of the each four indispensable amino acids both to crude protein and to sum of indispensable amino acids is apparently predictable value positioned on rather narrow limits. The equilibration of amino acid content in a diet in compliance with organism needs is an essential element of the sturgeons full nutrition during pre-spawning period $[19,20]$. When determining these needs the types and quantity of indispensable amino acids are established to appear in the forage for growth and vital activity of fish. Shortage of any essential amino acid inevitably confines use of other amino acids for protein synthesis thus reducing its efficiency [21,22]. Amino acid content in developed recipes is presented in Table 3 . The basic indices of fish productivity were estimated from their body enlargement speed and muscle bulk extension. Measuring of fish was conducted by the following formulae.

Pure gain was determined by the formula [2].

$\mathrm{Pg}=\mathrm{M}_{\mathrm{f}}-\mathrm{M}_{\mathrm{i}}$,

where $M_{f}$ is final mass of the juvenile, $g ; M_{i}$ is initial mass of the juvenile, g.

Mean daily gain was determined by the formula $[2,14]$

$\mathrm{P}=\left(\mathrm{M}_{\mathrm{f}}-\mathrm{M}_{\mathrm{i}}\right) / \mathrm{t}$,

where $P$ is mean daily gain, $g ; M_{f}$ and $M_{i}$ - are final and initial mass of the fish respectively, $\mathrm{g} ; \mathrm{t}$ - term of breeding, days.

Mean daily growth rate was determined by the compound interest formula [12]:

$$
A=\left[\left(M_{\mathrm{K}} / M_{0}\right) 1 / t-1\right] \cdot 100(\%),
$$

where $A$ is mean daily growth rate, $\% ; M_{к} и M_{o}$ - respective mass of fish in the beginning and in the end of experiment; $t$ - duration of the experiment, days.

Comparative assessment of fattiness was determined by Fultone coefficient expressed in formula [8]:

$\mathrm{Q}_{\mathrm{F}}=\left(\mathrm{P}^{\star} 100\right) / \mathrm{L}^{3}$,

where $Q_{F}$ is fattiness ratio;
$\mathrm{P}$ - mass of fish (mg.);

$\mathrm{L}$ - length of fish (mm.) from the snout to the overall height of the caudal fin.

Feed ratio was determined as proportion of expended fodder to mass extension of fish during the experiment.

Feed expense were determined by the formula [8]:

$\mathrm{K}=\mathrm{C}_{\mathrm{f}} /\left(\mathrm{m}_{\mathrm{f}}-\mathrm{m}_{\mathrm{i}}\right)$,

where $\mathrm{C}_{\mathrm{f}}$ is amount of fodder expensed during the breeding term,

$\mathrm{m}_{\mathrm{f}}$ is final mass of the fish,

$\mathrm{m}_{\mathrm{i}}$ - initial mass of the fish.

Physiological state of juvenile Russian sturgeon was determined by indications of total protein concentration and hemoglobin concentration. Erythrocyte sedimentation rate (ECR) showed whether there was any pathology. We took blood specimen by means of medical syringe from tail vein, farther settled it in the vial till total segregation of plasma and corpuscles, then poured the serum by means of medical syringe into another clean vial. Cells, tissue and organ morphology of the juvenile Russian sturgeon s was explored on

\begin{tabular}{|c|c|c|}
\hline Ingredients & \multicolumn{2}{|c|}{ Content, \% } \\
\hline Fish flour & 47 & 38 \\
\hline Fish oil & 9 & 18 \\
\hline Flour from crustaceans & 5 & 5 \\
\hline Blood flour & 5 & 10 \\
\hline Wheat gluten & 10 & 8 \\
\hline Corn gluten & 8 & 10 \\
\hline Wheat germ flakes & 10 & 5 \\
\hline Fodder yeast & 5 & 1 \\
\hline Premix (VMP PO-5) & 1 & 45 \\
\hline (vitamin-mineral supplement) & 12 & 22 \\
\hline & Overall content, \% & 16,4 \\
\hline Crude protein & 52 & 0,9 \\
\hline Crude fat & 0,9 & 7,4 \\
\hline Crude carbohydrates & 10,0 & 19,9 \\
\hline Crude cellulose & 17,4 & \\
\hline Crude ash & 12 & \\
\hline Total energy, mJ/kg & & \\
\hline
\end{tabular}

Table 1: A scheme of prosecution of experiment in evaluation of the efficiency of mixed fodder usage for commodity sturgeon farming, with various contents of fish oil.

\begin{tabular}{|c|c|}
\hline Elements & \% \\
\hline Crude protein & 68.0 \\
\hline Lysine & 5.44 \\
\hline Methionine & 2.04 \\
\hline Methionine \pm Cystine & 2.72 \\
\hline Tryptophane & 0.75 \\
\hline Arginine & 4.01 \\
\hline Histidine & 1.56 \\
\hline Phenylalanine & 2.79 \\
\hline Threonine & 2.79 \\
\hline Valine & 3.33 \\
\hline Leucine & 5.10 \\
\hline Isoleucine & 2.99 \\
\hline
\end{tabular}

Table 2: The protein and indispensable amino acids content in fish flour produced of fresh anchovy sprat 


\begin{tabular}{|c|c|c|c|}
\hline \multirow{2}{*}{ Amino acid } & \multicolumn{2}{|c|}{ Protein to fat ratio } & \multirow{2}{*}{$\begin{array}{l}\text { Amino acid need of fish \% } \\
\text { (Tscherbina and Gamygin 2006) }\end{array}$} \\
\hline & $52 / 12$ & $45 / 22$ & \\
\hline \multicolumn{4}{|c|}{ Indispensable } \\
\hline Lysine & 4.49 & 4.2 & 4.1 \\
\hline Methionine & 1.45 & 1.49 & 1.0 \\
\hline Tryptophane & 0.75 & 0.68 & - \\
\hline Arginine & 4.71 & 4.38 & 3.1 \\
\hline Histidine & 1.89 & 1.76 & 0.7 \\
\hline Leucine & 4.83 & 4.4 & 4.8 \\
\hline Isoleucine & 3.9 & 2.6 & 3.5 \\
\hline Phenylalanine & 3.2 & 2.9 & 2.6 \\
\hline Threonine & 2.92 & 2.5 & 2.9 \\
\hline Valine & 3.74 & 3.4 & 3.3 \\
\hline \multicolumn{4}{|c|}{ Replaceable } \\
\hline Cystine * & 1.03 & 0.75 & 0.9 \\
\hline Glycocoll & 2.9 & 2.4 & 2.1 \\
\hline Tyrosine * & 1.4 & 1.2 & 1.1 \\
\hline
\end{tabular}

* - conditionally replaceable

Table 3: Amino acid content of experimental variants of diets for pre-spawning maintenance of sturgeon breeders for the purpose of improving the quality of fertilized hard and food roe

series of histologic specimen prepared by standard methods [23]. After fixing the samples underwent dehydration in alcohol with increasing concentration $\left(60^{\circ}, 70^{\circ}, 80^{\circ}, 90^{\circ}, 96^{\circ}\right.$, absolute alcohol). The exposition term in each alcohol was 24 hours. Then the specimens were for 2-3 days steeped into photoxylin-castor oil (1:1). After that the material was successively placed in chloroform for 3 hours; chloroform-paraffin mixture at $37^{\circ} \mathrm{C}$ for night; in pure paraffin at $56^{\circ} \mathrm{C}$ for $30-40$ minutes. After that the material was poured into paraffin and quenched in cold water. We examined gametal cells structure by slicing paraffin blocks into sagittal pieces on standard microtome. We straightened series of slices 4-5 micro tons depth in a drop of warm water and stuck onto the object-plates polished with protein-glycerin mixture. Before imbuing the plates with slices had been dewaxed in xylene, xylene was removed by alcohols with falling concentration [7]. In total we made 62 microscopic sections. For imbuing the specimens we used Heidenhein's iron hematoxylin and Mallory azan stain. Then we put imbued slices into Canada balsam under the cover glass. The slices were assayed under a microscope Biolam Lomo. Specimens were examined under a microscope OLYMPUS BX40. The pictures were taken with digital ocular camera for microscope DSM. The results were subjected to statistical review. All the digital experiment data were processed on IBM PS/AT assisted with integrated package Statistica v 6.0, Microsoft Office Excel 2007 was also in use. The veracity of differences in compared indices was determined by Student criterion [24] (Figures 3 and 4$)$.

\section{Research Results}

With all-round reduction in population level of the Sturgeon in natural bodies of water opportunity of productive herds rejuvenating at the expense of naturally generated breeders is almost completely limited. Therefore broodstock management is based on "from egg to egg" raising of mature individuals or on domesticating of males and females sourced from wild population if it is possible. Possibility of acquiring mature individuals, frequently with excess fat gonad uptake, grown at commodity farms is not excluded. It causes breeding potential decrease of such fish and complexity in process of roe produced for food deriving $[23,24]$. At sturgeon hatcheries of Astrakhan oblast winter females' hard roe, stocking of which decreases every year, was compared with domesticated breeders roe and some sufficient differences in fat buildup level both in roe and in egg were registered. It testifies of gradual obesity and affected fertilization and survivability of eggs (Table 4). High fat in roes of domesticated females results from dietary features and application of fat-laden feed compound $(18 \%$ and more) particularly. Such roes were larger in size and noted for high fat and lower protein level. During spawning campaign those roes were poorly fertilized, seldom got off the ovaries, badly ovulated under gonadotropic hormone. Oocytes histological studies on the second stage (or second fat stage) are represented on (Figures 5 and 6). Considerable part of examined fish turned out to have oocyte structure abnormalities appeared in tunic destruction. Outer divergences were caused by changes in protein and lipid composition of oocytes resulted from disbolism and misbalance in the organism because of unbalanced diet. Most females had ovary hyperemia. Their ovaries were bloodfilled what was presumably caused by blood stream deceleration after "obesity of the roes" (Figure 7). Moreover nucleolus hypertrophy, occurrence of additional centers in cytoplasm and appearance of indistinctive stippling accounted for necrosis were noticed (Figure 8). Significantly deformated cells also occurred. Deformation of oocytes results from turgor impairment in membranes and decrease of their strength. Such oocytes had indefinite shape (Figure 9). Different kinds of oocytes abnormalities appeared to be caused by direct influence of misbalanced feeding of females during pre-spawning maintenance. Revealed abnormalities in some indices of lipid and protein composition in the roes of Russian sturgeon breeders were accounted for non-observance of farming conditions during pre-spawning period and applying of misbalanced diets. The most frequent problems of commodity sturgeon farming are the following: breakdown in biotechnology of aquacultural objects cultivation, absence of feeding schedule tight control, applying of feed compound with misbalanced nutrients composition, excess fish-holding density per unit of farming area. Figure 10 represents adipose degeneration of gonads of Russian sturgeon female on the third maturity. Such roes are unapt for food. Aforementioned factors cause occurrence of fat accumulation in gonads that result in troubles with intravital roe processing, short extraction

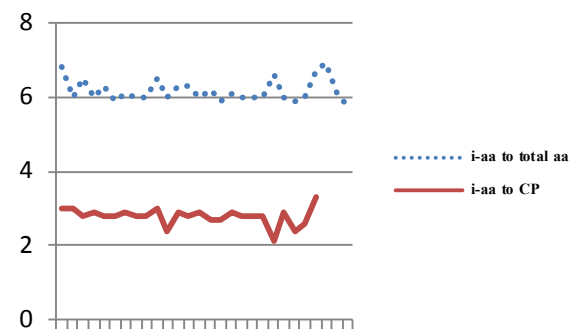

Figure 3: Methionine to crude protein and sum of i-AA ratio in fish flour.

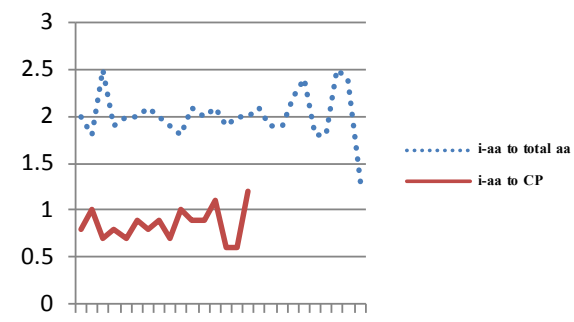

Figure 4: Cystine to crude protein and sum of i-AA ratio in fish flour. 
Citation: Fedorovykh JV, Ponomarev SV, Bakaneva JM, Bakanev NM, Sergeeva JV, et al.(2015)The Effect of Lipid Composition in Diets on Ovicell Generating of the Russian Sturgeon Females. J Aquac Res Development 6: 334. doi:10.4172/2155-9546.1000334

Page 4 of 6

\begin{tabular}{|c|c|c|c|}
\hline \multirow[b]{2}{*}{ Indices } & \multicolumn{2}{|c|}{ Domesticated females } & \multirow[b]{2}{*}{ Winter females } \\
\hline & $\begin{array}{l}\text { Matured in artificial } \\
\text { conditions for the first } \\
\text { time }\end{array}$ & $\begin{array}{l}\text { Matured in artificial } \\
\text { conditions for the } \\
\text { 3-4-th time }\end{array}$ & \\
\hline Dry matter & $39.4 \pm 1.1$ & $38.1 \pm 2.5$ & $37.4 \pm 4.4$ \\
\hline Protein & $25.8 \pm 0.5$ & $24.2 \pm 2.1$ & $27.3 \pm 3.5$ \\
\hline Fat & $13.3 \pm 1.5$ & $12.9 \pm 1.0$ & $8.7 \pm 1.2$ \\
\hline Mineral matters & $1.2 \pm 0.4$ & $1.6 \pm 0.2$ & $1.6 \pm 0.3$ \\
\hline
\end{tabular}

Table 4: Biochemical structure of Russian sturgeon roe ( $\%$ of raw matter)

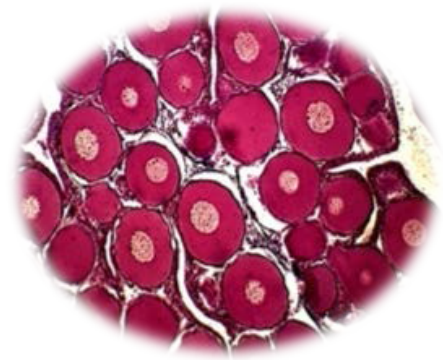

Figure 5: Russian sturgeon ovary in the second maturity (normal feature) (magnification 22x10).

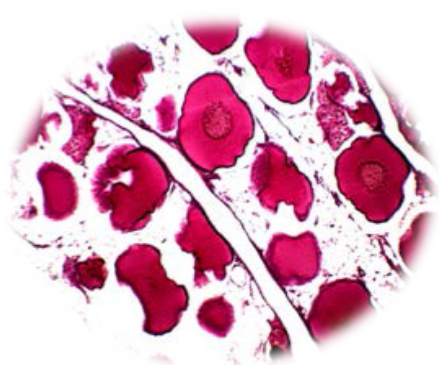

Figure 6: Oocytes degeneration in the Russian sturgeon ovary in the second maturity (magnification $22 \times 10$ ).

of gonad products from body weight, difficulties in processing such gonads for food. Fat in sturgeons' nutrition has been long estimated only in respect to energy value. Later on biological value of fat proved to depend on presence of indispensable (essential) polyunsaturated fatty acids. Among PUFAs are linolenic and linolic acids as well as their derivatives - eicosapentaenoic, docosahexaenoic and arachidonic acids generated over series of intermediate stages by prolongation of hydrocarbon chain and desaturation at the expense of olefinic linkages increase:

$\begin{array}{lcc}\text { 1. Linolenic }(18: 3 \omega-3) & \begin{array}{c}\text { Eicosapentaenoic } \\ (20: 5 \omega-3)\end{array} & \begin{array}{c}\text { Docosahexaenoic } \\ (22: 6 \omega-3)\end{array} \\ \text { 2. Linolic }(18: 2 \omega-6) & \begin{array}{c}\text { Arachidonic } \\ (20: 4 \omega-6)\end{array} & \end{array}$

Distillation characteristic of fundamental polyunsaturated fatty acids for the sturgeons was ascertained to content within the $9 \%$ mark of fish oil application into feed composition (Figure 11). Such fat is processed from maritime commercial fishes dwelling in northern seas and whose total lipids comprise a lot of PUFA $\omega$ 3: pentaenic and hexaenic AA. PUFA is an important factor of reproductive process of the sturgeons. The deficit of $\omega 3$ acids in fish forage causes fertility reduction, roe quality degradation, reduction of uncombined embryo exclusion, increasing number of deformed larvae and their death. Working on estimating of fish oil level influence on efficiency of commercial cultivation we divided all the fish into control and experimental groups. During the experiment we apply dry feed with fat content of 9 and $18 \%$. On the first work stage it was necessary to estimate influence of $18 \%$ (total content - $21 \%$ ) fish fat composition in the forage on pisciculture-biological indices of sturgeon farming in reservoirs without application of live food. When carrying out the experiment we use herring sardine fish oil which contained $20 \%$ of unsaturated fatty acids, $45 \%$ of oleinic acid $(\omega 9), 25 \%$ of fatty acids of $\omega 3$ tier and $10 \%$ of fatty acids of $\omega 6$ tier. The quality of oil was high (peroxide value - 0.12 unit, acid number - 15 units). The research results generally proved that excess increase in fish oil quantity in forage results in decrease of pisciculture biological indices. The best growth indices were achieved in control variant with fish oil content of $12 \%$ (totally with fish flour fat) in the food mix. The growth of body weight of fishes was 27 grams more than experimental variant with double the amount of fish oil (18\%) in forage, totally with fish flour fat $21 \%$. Survivability of fish was $100 \%$ in both variants. However the individuals in experimental group behaved less active, they were marked with low mobility and slow growth rate under increased feed expenses (Table 5). Coefficient of weight accumulation of the control variant fish with $9 \%$ of fish oil contents in the forage was high and amounted 0,035 units while the index of experimental variant with $18 \%$ content of fish oil was about 0,008 units, it corroborates natural growth rate reduction. However the question of the function lipid structures of fodder fat including unsaturated fatty acids perform remains obscure. Thus as the result of the experiment supplement of production forage with $18 \%$ of fish oil (totally 21\%) was determined to cause some reduction of growth rate. It relates to the fact that excess fat in fish mixed fodders induces hepatic accumulation of decomposition products that may cause fatty degeneration of liver. Growth rate of fish on mixed fodders supplemented with $9 \%$ of fat (totally $12 \%$ ) was consistently high during all the time of experiment. It is a matter of fact that in order to improve

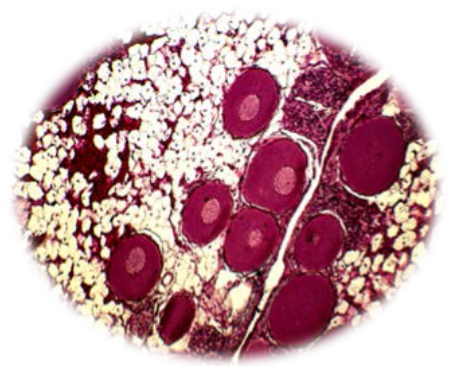

Figure 7: - Ovary hyperemia of the second maturity

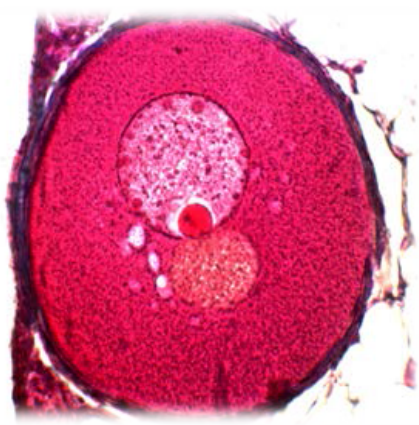

Figure 8: Nucleolus hypertrophy 


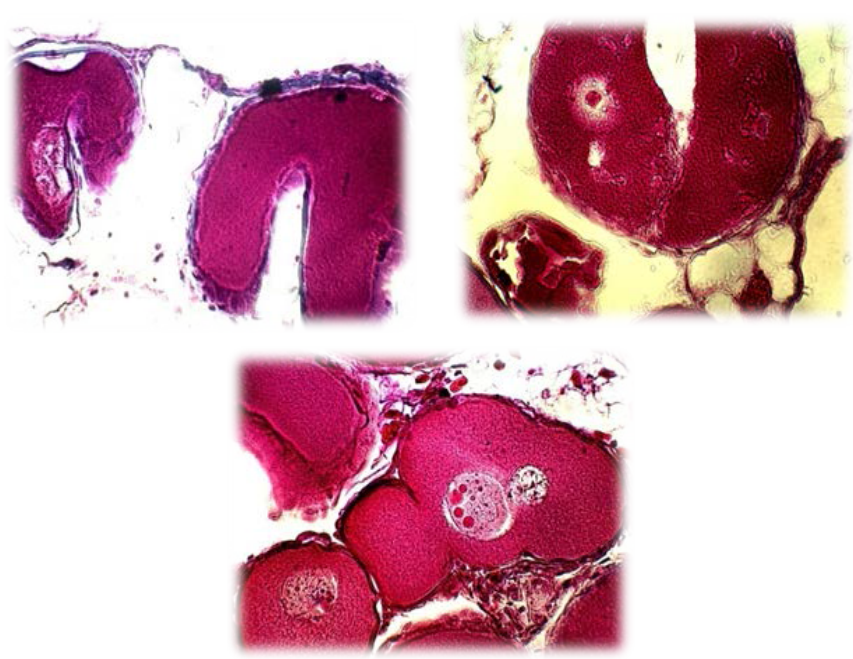

Figure 9: Deformated gametal cell of Russian sturgeon female in pre-spawning period.
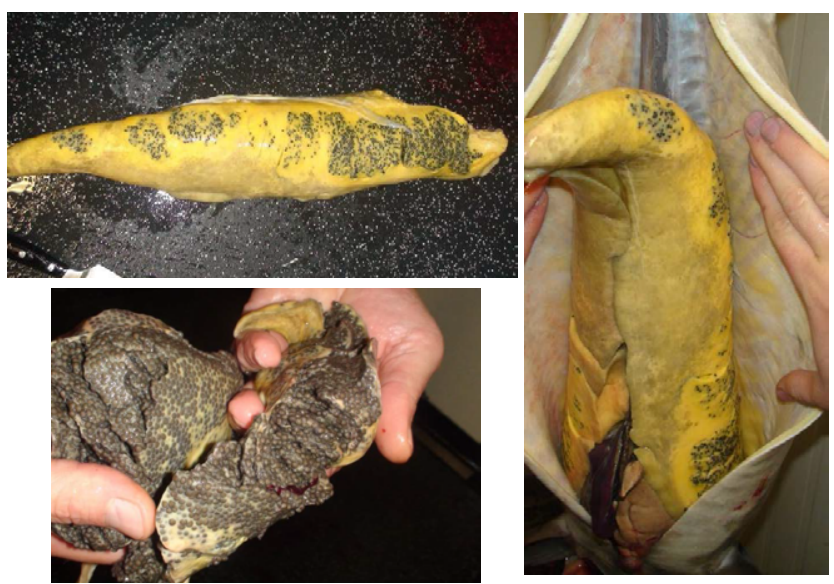

Figure 10: Gonads of Russian sturgeon entirely covered with fat following misbalanced diet.

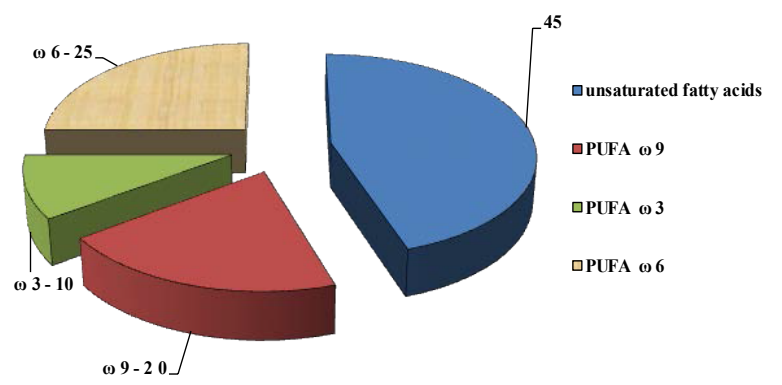

Figure 11: Contents of unsaturated fatty acids in fish oil in feed $\%$ of total amount.

pisciculture-biological indices of sturgeon mixed foddered breeding meant for commercial farming fat-containing ingredients should be expediently added subject to standards [8,21]. Optimal rate of herring sardine fish oil addition to the mix fodder for the sturgeons equals $9 \%$ (with total quantity in fodder $12 \%$ ). Fish oil concentration to $18 \%$ (i.e.
21\%) results in reducing of all abovementioned pisciculture-biological indices of farmed fish growth and maturation. At the same time determined hematologic indices of the farmed sturgeons which had been fed with production fodder with various content of supplementary fish oil allowed to calculate the best physiological status of fish (Table 6). Higher hemoglobin and erythrocytes content in the blood of fish with $9 \%$ of fat variant is evidence of positive effect of its lower contents in fodder. On females age of two and three histological research of their gonad products was carried out (Figures 12 and 13). The gametal gonads of all the examined three years old species were of the second maturity stage. The oviparous laminae were well-formed. Histoplogical specimens indicated numerous oocytes at the various stages of protoplasmatic growth which formed elder gametal cells generation. Their development proceeded without apparend deviations (with the exception of some few deformated ones). Expanded sanguineus blood vessels and blood cells clumps beyond the vascular bed were found in some sites. Thus conducted complex analysis of pisciculture-biological and physiological findings as the experimental results allowed us to set this standard. At the same time recalculation of fatty acids of $\omega 3$ and $\omega 6$ tiers allowed to determine their contents in quantity of 3 and 1,2 (in total lipids), percentage of fodder mass. The values of PUFA of linolenic $(\omega 3)$ and linolic $(\omega 6)$ tiers $-1-1,5 \%$ are similar to the ones of salmon family $(1,5-2,0)$.

\section{Discussion}

Addition of fish oil in number of $9 \%$ (with 12-13\% total fat content in mixed fodder) proved to be an optimal rate of mixed fodder supplement with fish oil for both commodity sturgeon farming and pre-spawning maintenance of breeders with the view of improving the quality of the live fertilized roes and caviar alike. According to the data of biochemical analyses of the sturgeons body composition, hematological indices, growth rates and general condition of the cultivated fish the effect was rather positive. At a minimum expenditure of fodder the body weight gain of the fish body in these series of experiments amounted $3.2 \%$ with maximum possible level of survivability (100\%). Besides being highly

\begin{tabular}{|c|c|c|}
\hline \multirow{2}{*}{ Indices } & \multicolumn{2}{|c|}{ Variants } \\
\cline { 2 - 3 } & Control (9\%) & Experiment (18\%) \\
\hline Initial mass, grams & $243.59 \pm 4.4$ & $242.44 \pm 4.35$ \\
\hline Final mass, grams & $288.04 \pm 2.87^{\star * *}$ & $260.35 \pm 4.16^{\star * *}$ \\
\hline Pure gain, grams & 45 & 18 \\
\hline Average daily gain, grams & 1.5 & 0.6 \\
\hline Average daily gain, $\%$ & 5.44 & 4.94 \\
\hline Survival rate, $\%$ & 100 & 100 \\
\hline Feed expense & 1.1 & 1.5 \\
\hline Breeding time, days. & 30 & 30 \\
\hline
\end{tabular}

Note: differences are clean under ${ }^{* * *}-\mathrm{P} \leq 0.001$

Table 5: Pisciculture-biological indices of hybrid sterlet $x$ beluga breeding on the forage with various fish oil contents

\begin{tabular}{|c|c|c|}
\hline \multirow{2}{*}{ Indices } & \multicolumn{2}{|c|}{ Experimental variants } \\
\cline { 2 - 3 } & Control (9\%) & Experiment (18\%) \\
\hline Hemoglobin, g/dL & $78.34 \pm 0.72^{\star * *}$ & $73.64 \pm 1.2^{\star * *}$ \\
\hline Hematocrit, \% & $28.24 \pm 0.44^{* * *}$ & $24.52 \pm 0.89^{* * *}$ \\
\hline Erythrocytes, million per $\mathrm{mm}^{3}$ & $0.894 \pm 0.012$ & $0.840 \pm 0.03$ \\
\hline $\begin{array}{c}\text { Hemoglobin content of an } \\
\text { erythrocytes, } \mu \mathrm{p} \text { /erythrocyte. }\end{array}$ & $6.8 \pm 0.11^{*}$ & $6.39 \pm 0.12^{*}$ \\
\hline Serum protein, $\mathrm{g} \%$ & $3.8 \pm 0.098$ & $2.37 \pm 0.1$ \\
\hline
\end{tabular}

Note: differences are clean under * $-\mathrm{P} \leq 0.05 ;{ }^{* * *}-\mathrm{P} \leq 0,001$

Table 6: Hematologic indices of Russian sturgeon bred on production fodder with various fish oil contents. 
Citation: Fedorovykh JV, Ponomarev SV, Bakaneva JM, Bakanev NM, Sergeeva JV, et al.(2015)The Effect of Lipid Composition in Diets on Ovicell Generating of the Russian Sturgeon Females. J Aquac Res Development 6: 334. doi:10.4172/2155-9546.1000334

Page 6 of 6

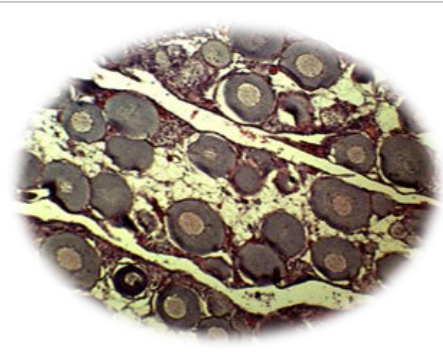

Figure 12: Ovary of Russian sturgeon female. The second stage of gonads maturity. (2 years old). Hematoxylin and eosin stain. Magnification 22x10. 1.

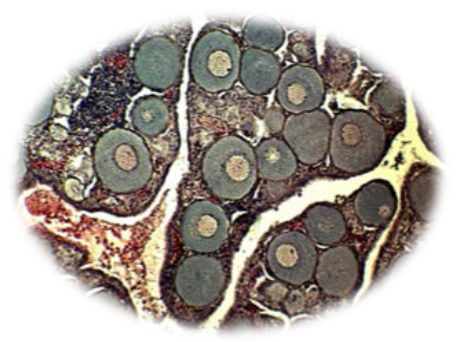

Figure 13: Ovary of Russian sturgeon female. The second stage of gonads maturity. ( 3 years old). Hematoxylin and eosin stain. Magnification $22 \times 10$. 1.

nourishing fish oil also attracting.

\section{References}

1. Zagrebina ON, Khasanipur AA, Kokoza AA (2014) Morphophysiological indices of juvenile Russian sturgeon and its hybrid with Siberian sturgeon. Harmonious exploration and preservation of aquatic bioresources. Rostov-onDon publishers, Russia.

2. Ostroumova IN (1987) The improvement of recipe of diets and methods of fish feeding in industrial farming.

3. Cowey CB (1980) Protein metabolism in fish.

4. Ostroumova IN (2012) Biological basics of feeding.

5. Glencross BD, Booth M, Allan GL (2007) A feed is only as good as its ingredients - a review of ingredient escalation strategies for aquaculture feeds. Aquaculture Nutrition 13: 17-34

6. Ponomarev SV, Grozesku JN, Bakhareva AA (2013) Fodders and feeding of fish in aquaculture: Manual. Moscow.

7. Gamygin EA, Bagrov AM (2013) Some aspects of feeding and fodder production for fish at the present days.

8. Bakaneva JM, Bakanev NM, Fedorovykh JV (2014) Effect of disbalanced die on roe quality of the sturgeon females.

9. Halver JE (1978) Lipids and fatty acids.

10. Ponomarev SV (2010) The estimation of the diets with various fat contentions for sturgeon.

11. Watanabe T (1979) Sparing action of lipids on dietary. Protein in protein fishlow protein diet with high calorie content.

12. Volkova OV, Eletsky YK (1982) Foundations of histology with histological technique.

13. Romeis B (1954) Microscopic technique.

14. Halver JE (1972) Fish nutrition.

15. Watanabe T (1982) Lipid Nutrition in Fish. Comp Biochem Physiol 73: 3-15.

16. Laqin GF (1990) Biometrics. Vysshaya shkola, Moscow.

17. Ponomareva EN, Bakhareva AA (1999) New polyvitamin premix for sturgeons The materials of the Second International symposium "Resource saving technology in aquaculture".

18. Sherbina MA, Gamygin IA, Salkova IA (1996) The influence of extrusion on the nutrition of feed raw materials for fish

19. Castell JD, Tiews K (1979) Report of the EIFAC, IUNS and ICES Working Group on the standardization of the methodology in fish nutrition research.

20. Corraze G (1994) Nutrition lipidique des poisons: imprortance et consequenced La piscicult franc 117: 25-36.

21. Hasan MR (2001) Nutrition and feeding for sustainable aquaculture development in the third millennium.

22. Jauncey K (1995) Advances freshwater fish nutrition.

23. Woodgate SL (2004) Creating alternative protein sources for aquafeeds using applied enzyme technologies. Nutritional Biotechnology in the Feed and Food Industries, Proceedings of Alltech's Twentieth Annual Symposium, Kentucky, USA.

24. Xu R, Hung SSO, German JB (1996) Effects of dietary lipids on the fatty acid composition of triglycerides and phospholipids in tissues of white Sturgeon. Aquas Nutr 2: 101-109. 